\title{
THE EFFECT OF GENOTYPE ON PRODUCTION AND SLAUGHTER PROPERTIES OF BROILER CHICKENS
}

\author{
V. Petričević, Z. Pavlovski, Z. Škrbić, M. Lukić \\ Institute for Animal Husbandry, Autoput 16, 11080 Belgrade-Zemun, Republic of Serbia \\ Corresponding author: Veselin Petričević, e-mail: veselin5@live.com \\ Original scientific paper
}

\begin{abstract}
Objective of the research was to investigate the effect of genotype on production and slaughter properties of broiler chickens. The usual technology of broiler production was implemented, therefore fattening lasted 42 days. Trial included total of 2070 broiler chickens of following hybrids: Cobb 500, Ross 308 and Hubbard Classic. Chickens of genotypes Cobb 500 and Ross 308 realized significantly higher average body masses compared to Hubbard chickens. The highest mortality rate in the trial was recorded in Hubbard genotype. Chickens Cobb 500 and Ross 308 had the same feed conversion and statistically insignificant differences in production indices, whereas the values of these parameters in Hubbard chickens were significantly less favourable. The breast depth as carcass conformation measure showed no statistically significant differences between genotypes. Significantly higher values of breast angle were established in chickens of Cobb 500 compared to other two genotypes, whereas the highest values of thigh girth and the metatarsus length were established in Ross 308 chickens. Better slaughter results were obtained in carcasses of Cobb 500 genotype, chickens of both genders. Share of abdominal fat in percentage was similar in all genotypes, so the genotype had no significant effect on variation of this trait.
\end{abstract}

Key words: broiler chickens, genotype, production results and slaughter properties.

\section{Introduction}

Test of broiler chickens is common selection measure carried out all over the world. The first broiler test in our country was carried out in 1967, Ejdupović et al. (1967), in order to compare production properties of domestic and foreign proveniences. Since 1991, there is no domestic poultry selection. Testing of different genotypes today is done in order to compare production and slaughter properties of foreign proveniences of fattening chickens. Identification of genetically superior hybrids is of great importance for production. 
For production of poultry meat in our country various hybrids are used, among which the following are predominant: Cobb 500, Ross 308, Hybro and Hubbard Classic. Comparison of their production performances in our rearing conditions is very important and interesting.

Slaughter/carcass properties of different genotypes are always relevant subject of research. Quality of processed carcasses of broiler chickens can be evaluated from several aspects. Slaughter yields and presence of abdominal fat in carcass are major elements which determine the quality of processed carcasses of broiler chickens. Numerous factors influence these, as well as other elements of the quality of broiler meat. Of biological factors, genotype and gender have the greatest influence on the carcass quality, Bošković-Bogosavljević et al. (2004).

Objective of this research was to determine the production and slaughter/carcass properties of broiler chickens of different genotypes which are present on our market.

\section{Materials and Methods}

Trial was carried out during March and April 2010, in Experimental centre of Institute for Animal Husbandry. As trial material, 690 one day old broiler chickens of every genotype - Cobb 500, Ross 308 and Hubbard Classic were selected. Chickens of every studied genotype, i.e. provenience were housed in six boxes according to random block system, so that the effect of potential differences in the environment would be reduced to the minimum. Chickens were fed 4 mixtures during the trial. Composition of mixtures is presented in Table 1. Feeding was ad libitum, mixture composition was equal for all proveniences.

Mortality and consumption of feed were monitored per box, so that in the statistical processing of data unit of observation was the box. At the end of fattening (42 days) body masses of all chickens were measured.

Based on data on body mass, feed conversion and mortality, the value of production index was calculated according to formula:

$$
\text { Production index }=\frac{\text { Body mass }(\mathrm{kg}) \mathrm{x} \text { vitality }(\%) \times 100}{\text { Duration of fattening }(\text { days }) \times \text { feed conversion }(\mathrm{kg} / \mathrm{kg})}
$$


Table 1. Composition of mixtures used in the trial

\begin{tabular}{|l|c|c|c|c|}
\hline Components & $\begin{array}{c}\text { Pre-starter } \\
(1-10 . \text { Day }) \\
\%\end{array}$ & $\begin{array}{c}\text { Starter } \\
(11-20 . \text { Day }) \\
\%\end{array}$ & $\begin{array}{c}\text { Grower } \\
(21-32 . \text { Day }) \\
\%\end{array}$ & $\begin{array}{c}\text { Finisher } \\
\text { 33-42.Day) } \\
\%\end{array}$ \\
\hline Corn & 52.0 & 53.5 & 54.0 & 57.6 \\
\hline Soybean meal (44\% Cp) & 20.0 & 30.0 & 29.0 & 27.0 \\
\hline Extruded fullfat soybean & 18.0 & - & - & - \\
\hline Sunflower meal (33\% Cp) & - & 3.0 & 4.0 & 4.0 \\
\hline Fish meal & 4.0 & 4.0 & 2.0 & - \\
\hline Soybean oil & 2.0 & 5.5 & 7.0 & 7.0 \\
\hline Limestone & 1.2 & 1.0 & 1.4 & 1.6 \\
\hline Monocalcium Phosphate & 1.4 & 1.6 & 1.2 & 1.4 \\
\hline Salt & 0.2 & 0.2 & 0.2 & 0.2 \\
\hline Mikozel & 0.2 & 0.2 & 0.2 & 0.2 \\
\hline Premixture & 1.0 & 1.0 & 1.0 & 1.0 \\
\hline \multicolumn{5}{|c|}{ Chemical composition and nutritional value (\%) } \\
\hline Energy (Kcal) & 2974 & 3014 & 3080 & 3100 \\
\hline Crude proteins & 22.30 & 21.10 & 19.70 & 17.80 \\
\hline Crude fat & 6.80 & 8.40 & 9.60 & 9.70 \\
\hline Ca & 0.95 & 0.95 & 0.90 & 0.90 \\
\hline P Total & 0.76 & 0.74 & 0.70 & 0.70 \\
\hline P Available & 0.44 & 0.41 & 0.35 & 0.34 \\
\hline
\end{tabular}

Subsequent to fattening, by method of random sample, 10 male and 10 female chickens of each genotype were selected, and after $12 \mathrm{~h}$ starvation, measured and slaughtered. After slaughtering, carcasses were processed, and warm and cooled carcasses measured according to Rulebook on quality of poultry meat (1981). In this way the following carcasses were obtained:

- "conventional processing" - carcasses with head, neck, bottom leg parts and edible internal organs;

- "ready to roast" - carcasses with lungs and kidneys, heart, liver, stomach, spleen and neck;

- "ready to grill" - carcasses with lungs and kidneys, without heart, liver, stomach, spleen and neck.

In processing of carcass, abdominal fat was separated, i.e. fatty tissue which is not connected to the carcass. Obtained masses of carcass and abdominal fat were put in relation to pre-slaughter body mass of chickens. In this way, yields " conventional processing ", " ready to roast " and " ready to grill", were obtained, as well as share of abdominal fat in carcass. 
Conformation measures were determined according to method by Pavlovski and Mašić (1983):

- Metatarsus length was measured, using calliper, from the most prominent distal area of the foot (opposite the third finger) and area of tibia-metatarsal joint on metatarsus.

- Keel length was measured, using calliper, between final keel points.

- Breast depth indicates the curvature of the breast, measured also by calliper, between the cranial part of the keel and dorsal area between the first thoracic vertebrae.

- Thigh girth was measured, by using measuring tape, and it was expressed in $\mathrm{mm}$ indicating the widest part of the thigh.

- Breast angle is considered to be the most important conformation measure. It is the indicator of the development of musculature and its curvature. Breast angle is measured by protractor vertically in relation to the line of the back.

Index values of carcass conformation measures of tested broiler genotypes were obtained as relation between the pre-slaughter body masses of broiler chickens and adequate absolute values obtained for conformation measures.

Statistical processing of obtained data was done by using the software package "STATISTICA". Variance analysis was used as well as F-test to establish the presence of statistically significant differences. Tuckey test was used for determination of statistical significance of differences between mean values.

\section{Results and Discussion}

In Table 2, indicators of production traits of broiler chickens of three different genotypes are presented. Hubbard broilers had significantly lower body mass on $42^{\text {nd }}$ day, compared to broilers of genotypes Cobb 500 and Ross 308 . Significant differences in body masses between different genotypes of broiler chickens were determined in studies of Hopić et al. (1995) and Vračar et al. (1996). Results on average body masses obtained in our research are higher compared to mentioned studies as well as results obtained by Yalcin et al. (1996) and Farran et al. (1995).

Feed conversion in chickens of genotypes Cobb 500 and Ross 308 was significantly better compared to Hubbard chickens, and lower compared to research by Petrović et al. (2002) and Tolimir et al. (2002) and in concordance with the research of Hopic et al. (1996). Mortality during fattening in case of Hubbard genotype was most expressed, significantly lower mortality rate was recorded for other two genotypes. Our results are in accordance with results 
obtained by Hopić et al. (1996). Values of production index for Cobb 500 chickens and Ross 308 differ insignificantly, but these values are significantly better than values obtained for Hubbard chickens, and are result of lower mortality, better feed conversion and higher body masses at the end of trial. Values of production indexes established by this research were higher compared to data stated by Hopić et al. (1996), Petrović et al. (2002) and Vračar et al. (1996).

By comparison of production results obtained in our research with the results of broiler chickens realized 15 years ago, the selection and genetics progress in poultry production as the most industrialized branch of livestock production, is evident.

Table 2. Production traits of tested broiler genotypes

\begin{tabular}{|c|c|c|c|c|c|}
\hline \multicolumn{2}{|l|}{ Genotype } & $\begin{array}{c}\text { Body mass } 42 . \text { day, g } \\
\bar{x} \pm S d\end{array}$ & $\begin{array}{l}\text { Mortality, } \\
\%\end{array}$ & $\begin{array}{c}\text { Feed } \\
\text { conversion, } \\
\mathrm{kg}\end{array}$ & P.I. \\
\hline \multirow[t]{2}{*}{ Cobb 500} & $\begin{array}{l}\hat{0} \\
0 \\
+\end{array}$ & $\begin{array}{c}2658.35 \pm 270.81 \\
2278.33 \pm 258.93\end{array}$ & \multirow[t]{2}{*}{2.6} & \multirow[t]{2}{*}{$1.83^{\mathrm{A}}$} & \multirow[t]{2}{*}{$310.47^{\mathrm{A}}$} \\
\hline & $\hat{0}+q$ & $2449.17 \pm 324.90^{\mathrm{A}}$ & & & \\
\hline \multirow[t]{2}{*}{ Hubbard } & $\begin{array}{l}\hat{0} \\
+ \\
+\end{array}$ & $\begin{array}{l}2549.14 \pm 346.63 \\
2113.19 \pm 304.75\end{array}$ & \multirow[t]{2}{*}{9.28} & \multirow[t]{2}{*}{$2.11^{\mathrm{B}}$} & \multirow[t]{2}{*}{$234.43^{\mathrm{B}}$} \\
\hline & $\hat{0}+q$ & $2289.64 \pm 386.90^{\mathrm{B}}$ & & & \\
\hline \multirow[t]{2}{*}{ Ross 308} & $\begin{array}{l}0 \\
0 \\
+\end{array}$ & $\begin{array}{c}2746.47 \pm 273.73 \\
2283.50 \pm 263.22\end{array}$ & \multirow[t]{2}{*}{3.19} & \multirow[t]{2}{*}{$1.83^{\mathrm{A}}$} & \multirow[t]{2}{*}{$309.85^{\mathrm{A}}$} \\
\hline & $\hat{0}+0$ & $2462.85 \pm 349.68^{\mathrm{A}}$ & & & \\
\hline
\end{tabular}

Values are presented as $x \pm \mathrm{Sd}$

* A-B Average values in each column without common designations are significantly different at the level of $1 \%$

In Table 3, absolute values of carcass properties are presented. Statistically, significantly lower pre-slaughter body masses were recorded in chickens of both genders of Hubbard provenience, in comparison to Cobb 500 and Ross 308 chickens. Significantly lower absolute values of carcass properties of Hubbard chickens compared to other two genotypes in regard to masses of conventionally processed carcasses, masses of carcass „ready to roast“ and „ready to grill“ are consequences of significantly lower pre-slaughter masses of this hybrid. Established differences between genotypes Cobb 500 and Ross 308 for preslaughter body mass were not statistically significant, which can be concluded also for carcass masses ,,conventional processing“, „ready to roast“" and ,ready to grill“". 
Table 3. Absolute values of broiler slaughter/carcass properties of tested genotypes

\begin{tabular}{|c|c|c|c|c|c|}
\hline Genotype & Gender & $\begin{array}{l}\text { Pre-slaughter body } \\
\text { mass, } g\end{array}$ & $\begin{array}{l}\text { Mass "conventional } \\
\text { processing", g }\end{array}$ & $\begin{array}{l}\text { Mass "ready to } \\
\text { roast", g }\end{array}$ & $\begin{array}{l}\text { Mass "ready to } \\
\text { grill", g }\end{array}$ \\
\hline \multirow{3}{*}{ Hubbard } & $\hat{\sigma}$ & $2567.0 \pm 252.1$ & $2138.7 \pm 227.1$ & $1993.8 \pm 232.9$ & $1769.0 \pm 196.8$ \\
\hline & 오 & $2356.0 \pm 231.2$ & $1959.2 \pm 171.0$ & $1823.8 \pm 152.8$ & $1623.5 \pm 145.4$ \\
\hline & $\frac{+}{0+q}$ & $2461.5 \pm 259.1^{\mathrm{Bb}}$ & $2048.9 \pm 216.3^{\mathrm{B}}$ & $1908.8 \pm 210.6^{\mathrm{B}}$ & $1696.3 \pm 184.2^{\mathrm{B}}$ \\
\hline \multirow{3}{*}{$\begin{array}{l}\text { Cobb } \\
500\end{array}$} & $\delta^{+}$ & $2915.0 \pm 202.4$ & $2451.5 \pm 161.5$ & $2273.5 \pm 157.7$ & $2045.0 \pm 145.9$ \\
\hline & 우 & $2440.0 \pm 171.2$ & $2059.7 \pm 143.8$ & $1924.4 \pm 137.1$ & $1717.9 \pm 139.3$ \\
\hline & $\hat{0}+\phi$ & $2676.5 \pm 304.4^{\mathrm{Aa}}$ & $2255.6 \pm 250.1^{\mathrm{A}}$ & $2098.9 \pm 229.7^{\mathrm{A}}$ & $1878.5 \pm 217.8^{\mathrm{A}}$ \\
\hline \multirow{3}{*}{ Ross 308} & $\delta^{+}$ & $2910.0 \pm 183.8$ & $2437.9 \pm 142.3$ & $2262.9 \pm 140.1$ & $2040.7 \pm 127.1$ \\
\hline & 우 & $2390.0 \pm 165.9$ & $1996.6 \pm 128.2$ & $1867.6 \pm 118.2$ & $1665.9 \pm 101.2$ \\
\hline & $\hat{0}+\phi$ & $2650.0 \pm 316.6^{\mathrm{ABa}}$ & $2217.2 \pm 262.0^{\mathrm{A}}$ & $2065.2 \pm 238.8^{\mathrm{A}}$ & $1853.3 \pm 222.4^{\mathrm{A}}$ \\
\hline \multicolumn{6}{|c|}{ Assessment of significance } \\
\hline \multicolumn{2}{|l|}{ Genotype } & $\mathrm{p}<0.01$ & $\mathrm{p}<0.01$ & $\mathrm{p}<0.01$ & $\mathrm{p}<0.01$ \\
\hline
\end{tabular}

Values are presented as $x \pm \mathrm{Sd}$

* A-B Average values in each column without common designations are significantly different at the level of $1 \%$

* a-b Average values in each column without common designations are significantly different at the level of $5 \%$

Content and share of abdominal fat are presented in Table 4. The lowest share of abdominal fat was recorded in male birds of Hubbard provenience, and the highest in female chickens of Cobb 500 provenience. Differences between trial birds of different proveniences in share of abdominal fat were not statistically significant, so it can be said that shares of fat in the carcass were not under the influence of genotype, which is in accordance with results of Hopić et al. (1999), Hopić et al. (2000) and Bošković-Bogosavljević et al. (2004). Deviations which occurred can be attributed to differences in pre-slaughter body mass.

In Table 5, carcass yields ("conventional processing", "ready to roast" and "ready to grill") in broiler chickens of investigated genotypes, are presented. Based on data presented in table it can be concluded that chickens of genotype Cobb 500 had higher values for all three studied yields compared to broiler chickens of genotypes Ross 308 and Hubbard. Analysis of expressed differences from the aspect of the effect of genotype, significant differences between these three hybrids were established only for yield "ready to grill". 
Table 4. Content and share of abdominal fat in carcass

\begin{tabular}{|c|c|c|c|}
\hline Genotype & Gender & Content of abdominal fat, $\mathrm{g}$ & Share of abdominal fat, $\% \mathrm{BM}$ \\
\hline \multirow{3}{*}{ Hubbard } & $\hat{\sigma}$ & $24.4 \pm 9.5$ & $1.0 \pm 0.4$ \\
\hline & q & $26.7 \pm 10.9$ & $1.1 \pm 0.5$ \\
\hline & $\hat{0}+q$ & $25.5 \pm 10.0^{\mathrm{b}}$ & $1.0 \pm 0.4$ \\
\hline \multirow{3}{*}{ Cobb 500} & $\pi$ & $32.2 \pm 8.8$ & $1.1 \pm 0.3$ \\
\hline & q & $34.4 \pm 5.7$ & $1.4 \pm 0.3$ \\
\hline & $\hat{0}+q$ & $33.3 \pm 7.3^{\mathrm{a}}$ & $1.3 \pm 0.3$ \\
\hline \multirow{3}{*}{ Ross 308} & $\sigma^{\lambda}$ & $35.2 \pm 9.1$ & $1.2 \pm 0.3$ \\
\hline & q & $32.6 \pm 7.7$ & $1.4 \pm 0.4$ \\
\hline & $\hat{\sigma}+\phi$ & $33.9 \pm 8.3^{\mathrm{a}}$ & $1.3 \pm 0.3$ \\
\hline \multicolumn{4}{|c|}{ Assessment of significance } \\
\hline \multicolumn{2}{|c|}{ Genotype } & $\mathrm{P}<0.05$ & $\mathrm{p}=0.06$ \\
\hline
\end{tabular}

Values are presented as $\bar{x} \pm \mathrm{Sd}$

* a-b Average values in each column without common designations are significantly different at the level of $5 \%$

Females of Cobb 500 provenience had values for all three investigated yields compared to males of the same hybrid, but also compared to females and males of other two hybrids.

Table 5. Relative values of broiler slaughter/carcass traits of tested genotypes

\begin{tabular}{|c|c|c|c|c|}
\hline Genotype & Gender & $\begin{array}{l}\text { Yield "conventional } \\
\text { processing", } \%\end{array}$ & $\begin{array}{c}\text { Yield "ready to roast", } \\
\%\end{array}$ & $\begin{array}{c}\text { Yield "ready to grill", } \\
\%\end{array}$ \\
\hline \multirow{3}{*}{ Hubbard } & $\delta^{\lambda}$ & $83.3 \pm 1.9$ & $77.6 \pm 3.5$ & $68.8 \pm 1.3$ \\
\hline & 우 & $83.3 \pm 2.4$ & $77.5 \pm 2.6$ & $69.0 \pm 2.5$ \\
\hline & $\hat{o}+q$ & $83.3 \pm 2.1$ & $77.6 \pm 3.0$ & $68.9 \pm 2.0^{\mathrm{b}}$ \\
\hline \multirow{3}{*}{$\begin{array}{l}\text { Cobb } \\
500\end{array}$} & $\pi$ & $84.1 \pm 1.6$ & $78.0 \pm 1.4$ & $70.2 \pm 1.4$ \\
\hline & o & $84.4 \pm 1.3$ & $78.9 \pm 1.4$ & $70.4 \pm 1.7$ \\
\hline & $\hat{o}+q$ & $84.3 \pm 1.4$ & $78.4 \pm 1.4$ & $70.3 \pm 1.5^{\mathrm{a}}$ \\
\hline \multirow{3}{*}{ Ross 308} & $\hat{0}$ & $83.8 \pm 0.9$ & $77.8 \pm 1.5$ & $70.1 \pm 1.5$ \\
\hline & 우 & $83.6 \pm 1.1$ & $78.2 \pm 0.9$ & $69.7 \pm 1.3$ \\
\hline & $\hat{0}+q$ & $83.7 \pm 1.0$ & $78.0 \pm 1.2$ & $69.9 \pm 1.4^{\mathrm{ab}}$ \\
\hline \multicolumn{5}{|c|}{ Assessment of significance } \\
\hline \multicolumn{2}{|c|}{ Genotype } & $\mathrm{p}=0.14$ & $\mathrm{p}=0.41$ & $\mathrm{p}<0.05$ \\
\hline
\end{tabular}

Values are presented as $\bar{x} \pm \mathrm{Sd}$ 
* a-b Average values in each column without common designations are significantly different at the level of $5 \%$

Values of carcass traits established in this research are slightly lower than data stated by Bošković-Bogosavljević et al. (2004), Vračar et al. (1997) and Tolimir et al. (2002) and similar to results obtained by Pavlovski et al. (1987), Hopić et al. (1995) and Petrović et al. (2002).

In Table 6 and 7, absolute and index values of carcass conformation are presented. Chickens of Ross 308 hybrid had significantly longer metatarsus compared to Hubbard chickens, and significantly higher value of thigh girth, which contributed to better carcass conformation. Statistically, significantly higher value of breast angle characterized processed carcasses of Cobb 500 genotype compared to Hubbard. Significant differences in metatarsus length and breast angle in chickens of different genotypes were also established in research by Hopić et al. (1999) and Hopić et al. (2000). Established differences between genotypes for absolute values of keel length and breast depth were not statistically significant. Significantly lower index values of Hubbard chickens in regard to metatarsus length and keel length, as well as thigh girth indicated poorer carcass conformation properties of this hybrid compared to carcasses of Cobb 500 and Ross 308 broilers. Contrary to these researches, Vračar et al. (1997) and Hopić et al. (1995) did not establish in their research significance of differences for carcass conformation traits between studied hybrids.

Table 6. Broiler carcass conformation of tested genotypes (absolute values)

\begin{tabular}{|c|c|c|c|c|c|c|}
\hline Genotype & Gender & $\mathrm{ML}, \mathrm{mm}$ & $\mathrm{KL}, \mathrm{mm}$ & $\mathrm{BD}, \mathrm{mm}$ & Breast angle, degrees & $\mathrm{TG}, \mathrm{mm}$ \\
\hline \multirow{2}{*}{ Hubbard } & $\begin{array}{l}1 \\
0 \\
+\end{array}$ & $\begin{array}{l}81.0 \pm 4.7 \\
76.0 \pm 4.2\end{array}$ & $\begin{array}{l}123.7 \pm 3.8 \\
119.7 \pm 4.4\end{array}$ & $\begin{array}{l}92.5 \pm 4.0 \\
88.8 \pm 3.5\end{array}$ & $\begin{array}{l}125.6 \pm 4.2 \\
126.5 \pm 2.4\end{array}$ & $\begin{array}{l}156.7 \pm 8.1 \\
150.7 \pm 6.6\end{array}$ \\
\hline & $\hat{\sigma}+q$ & $78.5 \pm 5.0^{\mathrm{b}}$ & $121.7 \pm 4.5$ & $90.7 \pm 4.1$ & $126.1 \pm 3.4^{\mathrm{b}}$ & $153.7 \pm 7.9^{\mathrm{b}}$ \\
\hline \multirow{3}{*}{$\begin{array}{l}\text { Cobb } \\
500\end{array}$} & $\hat{0}$ & $83.3 \pm 3.7$ & $127.5 \pm 2.0$ & $96.0 \pm 4.5$ & $129.5 \pm 1.1$ & $161.4 \pm 9.8$ \\
\hline & 오 & $75.8 \pm 1.6$ & $119.6 \pm 3.4$ & $91.7 \pm 3.7$ & $127.8 \pm 3.4$ & $153.5 \pm 6.7$ \\
\hline & $\hat{0}+q$ & $79.5 \pm 4.8^{\mathrm{ab}}$ & $123.6 \pm 4.9$ & $93.8 \pm 4.6$ & $128.7 \pm 2.6^{\mathrm{a}}$ & $157.5 \pm 9.1^{\text {ab }}$ \\
\hline \multirow{3}{*}{ Ross 308} & 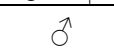 & $84.5 \pm 3.6$ & $126.0 \pm 3.4$ & $96.5 \pm 5.0$ & $127.2 \pm 4.0$ & $167.2 \pm 7.9$ \\
\hline & 우 & $78.3 \pm 3.3$ & $115.5 \pm 6.6$ & $90.0 \pm 5.3$ & $126.4 \pm 2.9$ & $153.9 \pm 8.3$ \\
\hline & $\hat{0}+q$ & $81.4 \pm 4.6^{\mathrm{a}}$ & $120.8 \pm 7.4$ & $93.2 \pm 6.0$ & $126.8 \pm 3.4^{\mathrm{ab}}$ & $160.6 \pm 10.4^{\mathrm{a}}$ \\
\hline \multicolumn{7}{|c|}{ Assessment of significance } \\
\hline \multicolumn{2}{|c|}{ Genotype } & $\mathrm{p}<0.05$ & $\mathrm{p}>0.05$ & $\mathrm{p}>0.05$ & $\mathrm{p}<0.05$ & $\mathrm{p}<0.05$ \\
\hline
\end{tabular}

Values are presented as $\bar{x} \pm \mathrm{Sd}$

* a-b Average values in each column without common designations are significantly different at the level of $5 \%$ 
Table 7. Index values of carcass conformation measures in tested broiler genotypes

\begin{tabular}{|c|c|c|c|c|c|}
\hline Genotype & Gender & $\mathrm{BM} / \mathrm{ML}, \mathrm{g} / \mathrm{mm}$ & $\mathrm{BM} / \mathrm{KL}, \mathrm{g} / \mathrm{mm}$ & $\mathrm{BM} / \mathrm{BD}, \mathrm{g} / \mathrm{mm}$ & $\mathrm{BM} / \mathrm{TG}, \mathrm{g} / \mathrm{mm}$ \\
\hline \multirow{3}{*}{ Hubbard } & $0^{\pi}$ & $31.7 \pm 2.5$ & $20.7 \pm 1.7$ & $27.7 \pm 1.9$ & $16.4 \pm 1.0$ \\
\hline & 오 & $31.0 \pm 2.1$ & $19.7 \pm 1.8$ & $26.5 \pm 2.2$ & $15.6 \pm 1.1$ \\
\hline & $\hat{o}+q$ & $31.3 \pm 2.3^{\mathrm{B}}$ & $20.2 \pm 1.8^{\mathrm{Bb}}$ & $27.1 \pm 2.1$ & $16.0 \pm 1.1^{\mathrm{b}}$ \\
\hline \multirow{3}{*}{$\begin{array}{l}\text { Cobb } \\
500\end{array}$} & $0^{1}$ & $35.0 \pm 2.2$ & $22.9 \pm 1.7$ & $30.4 \pm 2.4$ & $18.1 \pm 1.6$ \\
\hline & 우 & $32.2 \pm 2.1$ & $20.4 \pm 1.4$ & $26.6 \pm 1.5$ & $15.9 \pm 0.8$ \\
\hline & $\hat{0}+q$ & $33.6 \pm 2.6^{\mathrm{A}}$ & $21.6 \pm 2.0^{\mathrm{ABa}}$ & $28.5 \pm 2.8$ & $17.0 \pm 1.7^{\mathrm{a}}$ \\
\hline \multirow{3}{*}{ Ross 308} & $\hat{0}$ & $34.4 \pm 1.6$ & $23.1 \pm 1.5$ & $30.2 \pm 2.4$ & $17.5 \pm 1.6$ \\
\hline & q & $30.6 \pm 2.2$ & $20.7 \pm 1.3$ & $26.6 \pm 1.5$ & $15.6 \pm 1.2$ \\
\hline & $\hat{o}+q$ & $32.5 \pm 2.7^{\mathrm{AB}}$ & $21.9 \pm 1.9^{\mathrm{Aa}}$ & $28.4 \pm 2.7$ & $16.5 \pm 1.7^{\mathrm{ab}}$ \\
\hline \multicolumn{6}{|c|}{ Assessment of significance } \\
\hline \multicolumn{2}{|c|}{ Genotype } & $\mathrm{p}<0.01$ & $\mathrm{p}<0.01$ & $\mathrm{p}>0.05$ & $\mathrm{p}<0.05$ \\
\hline
\end{tabular}

Values are presented as $x \pm \mathrm{Sd}$

* A-B Average values in each column without common designations are significantly different at the level of $1 \%$

* a-b Average values in each column without common designations are significantly different at the level of $5 \%$

$\mathrm{BM}$ - pre-slaughter body mass

$\mathrm{BD}$ - breast depth

ML - metatarsus length

$\mathrm{TG}$ - thigh girth

$\mathrm{KL}$ - keel length

\section{Conclusion}

Based on research results obtained in the study of the effect of broiler genotype on production results, slaughter/carcass yields and share of abdominal fat, the following can be concluded:

Hubbard chickens realized after 42 days of fattening significantly lower average body mass compared to Cobb 500 and Ross 308 chickens.

Lower mortality, better feed conversion and higher value of production index were recorded in chickens of Cobb 500 and Ross 308 provenience compared to Hubbard chickens.

Yields "conventional processing" and "ready to roast" were not under the significant influence of genotype, whereas the yield »ready to grill« was significantly higher in chickens of Cobb 500 provenience compared to Hubbard chickens.

Values of conformation measures were under the influence of genotype. The greatest breast angle was recorded in Cobb 500 chickens, the longest metatarsus and the highest value of thigh girth in Ross 308 chickens, whereas the lowest index value for keel length and breast depth was recorded in chickens of Hubbard genotype.

Genotype also had no statistically significant effect on the share of abdominal fat in carcass. 
Based on established results it can be concluded that the results obtained for Hubbard genotype chickens in this investigation were inferior to those obtained for Cobb 500 and Ross 308.

\title{
Acknowledgment
}

Research was financed by the Ministry of Education and Science Republic of Serbia, project TR 31033.

\section{Uticaj genotipa na proizvodne i klanične karakteristike brojlerskih pilića}

\author{
V. Petričević, Z. Pavlovski, Z. Škrbić, M. Lukić
}

\section{Rezime}

Cilj istraživanja bio je da se ispita uticaj genotipa na proizvodne i klanične karakteristike brojlerskih pilića. Primenjena je uobičajena tehnologija gajenja tako da je tov trajao 42 dana. Ogledom je obuhvaćeno ukupno 2070 brojlerskih pilića hibrida: Cobb 500, Ross 308 i Hubbard Classic. Pilići genotipa Cobb 500 i Ross 308 su postigli značajno veće prosečne telesne mase od pilića genotipa Hubbard. Najveći procenat mortaliteta $u$ toku ogleda uočen je kod genotipa Hubbard. Istu konverziju hrane i statistički neznačajno različite proizvodne indekse postigli su pilići Cobb 500 i Ross 308, dok su vrednosti ovih parametara kod pilića Hubbard bile značajno nepovoljnije.

Dubina grudi kao mera konformacije trupa se nije statistički značajno razlikovala među genotipovima. Značajno veće vrednosti grudnog ugla imali su pilići Cobb 500 u odnosu na ostala dva genotipa, dok su najveće obime bataka i najveće dužine piska imali pilići Ross 308.

Bolji klanični rezultati su dobijeni na trupovima oba pola genotipa Cobb 500. Procentualno učešće abdominalne masti je slično kod genotipova, tako da genotip nije imao značajan uticaj na variranje ove osobine.

\section{References}

BOGOSAVLJEVIĆ- BOŠKOVIĆ S., ĐOKOVIĆ R., PETROVIĆ M., RADOVIĆ V. (2004): Odabrani parametri kvaliteta obrađenih trupova brojlerskih pilića. Biotecnology in Animal Husbandry, 20, 5-6, 181-186. 
EJDUPOVIĆ V., DUNĐERSKI M., ARAPOVIĆ Z. (1967): Rezultati prvog zvaničnog testa brojlera različitih provenijenci kod nas. Živinarski dani 1967. god. Referati domaćih autora. Ljubljana I, 21-35.

FARRAN M.T., UWAYJAN M.G., KHALIL R.F., ASHKARIAN V.M. (1995): Comparativeperformance and carass compositio on three sexed broiler strain. $16^{\text {th }}$ Annual Meeting of the Southern Poultry Sciennce, Poulttry Sci., Abstracts, S-45, 189. HOPIĆ S. (1999): Genotipska i fenotipska varijabilnost kvantitativnih svojstava pilića u tovu. Doktorska disertacija. Poljoprivredni fakultet - Novi Sad, 1999.

HOPIĆ S., PAVLOVSKI Z., MAŠIĆ B., VRAČAR S., ĐURĐEVIĆ Z. (1995): Proizvodne i klanične karakteristike različitih genotipova brojlerskih pilića. Biotehnologija u stočarstvu, 1-2, 27-35.

HOPIĆ S., PAVLOVSKI Z., VRAČAR S., ĐURĐEVIĆ Z. (1996): Proizvodne i klanične karakteristike brojlerskih pilića različitog genotipa. Nauka u živinarstvu, 1-2, 11-19.

HOPIĆ S., VIDOVIĆ V., MILOŠEVIĆ N., SUPIĆ B., PAVLOVSKI Z. (2000): Uticaj genotipa i godine na klanične osobine tovnih pilića. Biotecnology in Animal Husbandry, 17, 5-6, 47-53.

PAVLOVSKI Z., MAŠ́IĆ B. (1983): Konformacija trupova pilića. Kvalitet mesa i standardizacija, Zbornik radova, Bled 115-126.

PAVLOVSKI Z., MAŠIĆ B., MILOŠEVIĆ N., VRAČAR S. (1987): Uporedna ispitivanja proizvodnih osobina brojlera domaćeg i inostranog porekla. Peradarstvo, 5, 129-132.

PETROVIĆ D., PETROVIĆ M., TOLIMIR N., BOGOSAVLJEVIĆ-BOŠKOVIĆ S., PETROVIĆ M., BRKIĆ N. (2002): Uporedna analiza proizvodnih i klaničnih karakteristika dve provenijence brojlerskih pilića. Biotecnology in Animal Husbandry, 18, 5-6, 115-119.

Pravilnik o kvalitetu mesa pernate živine (1981): Službeni list SFRJ br. 1. januar 1981.god., 13-14.

TOLIMIR N., PETROVIĆ D., PETROVIĆ M., MASIĆ M., MALETIĆ R., BOGOSAVLJEVIĆ-BOŠKOVIĆ S. (2002): Uporedno ispitivanje proizvodnih i klaničnih osobina tri provenijence brojlerskih pilića. Savremena poljoprivreda, 51, 3-4, 223-226.

VRAČAR S., PAVLOVSKI Z., HOPIĆ S., LUKIĆ M., ŠKRBIĆ Z. (1996): Uporedno ispitivanje proizvodnih osobina brojlerskih pilića različitih genotipova. Nauka u živinarstvu, 3-4, 141-146.

VRAČAR S., PAVLOVSKI Z., HOPIĆ S., LUKIĆ M., ŠKRBIĆ Z. (1997): Uticaj genotipa na proizvodne i klanične karaklteristike brojlerskih pilića. Nauka u živinarstvu, 2, 3-4, 135-139.

YALCIN S., OSKAN S., SETTAR P., TOLON B. (1996): Influence of ambient temperature and genotype on bone parameters and incidence of leg disorders of male and female broilers. XX Worlds Poultry Conference, New Delhi, India, 2-5 Septembar 1996, Proc., II, 577-580. 